\title{
农作物传播视角下的欧亚大陆史前东西方文化 交流
}

董广辉 $1^{*}$, 杨谊时 ${ }^{1}$, 韩建业 ${ }^{2}$, 王辉 ${ }^{3}$, 陈发虎 ${ }^{1}$

1. 兰州大学西部环境教育部重点实验室, 兰州大学资源环境学院, 兰州 730000;

2. 中国人民大学历史学院, 北京 100872 ;

3. 甘肃省文物考古研究所, 兰州 730000

*E-mail: ghdong@1zu.edu.cn

收稿日期: 2016-12-07; 接受日期: 2017-03-24; 网络版发表日期: 2017-04-06

国家自然科学基金项目(批准号: 41620104007和41671077)、国家社会科学基金重大项目(编号: 12 \& ZD151)和兰州大学中央高校基本科研 业务费专项资金(编号：LZUJBKY-2015-K09)资助

\begin{abstract}
摘要＼cjkstart欧亚大陆东西方文化交流的历史是广受关注的科学问题, 考古证据显示至少可追溯至青铜时代早期, 但具体的时间和路线并不清楚. 文化交流过程伴随着农作物的传播与交换, 相对于考古遗物,农作物遗存鉴定 标准明确且可精确定年, 是研究文化交流过程的理想材料. 本文总结和对比了欧亚大陆史前遗址的植物大遗存 鉴定和直接测年数据, 以及人骨碳同位素分析结果, 系统梳理了东亚起源的农作物栗㯟西传, 西亚起源的农作 物小麦和大麦东传, 及其相互汇聚的时空过程. 结合其他考古材料, 探讨史前欧亚大陆东西方文化交流的过程. 结果显示, 约10500a BP起源于西亚地区的小麦和大麦在8000a BP之前传入欧洲和中亚西部, 4500 4000a BP传 入中亚东部和中国西北地区. 粟㯟在7700a BP之前驯化于中国北方, 4500 4000a BP传入中亚东部, 3500a BP后 传入西亚和欧洲. 约4400a BP在中亚东部的哈萨克斯坦地区出现㯟和小麦、大麦同时利用的迹象, 可能是东西 方文化元素最早汇聚的地区. 4500 3500a BP粟㯟和麦类作物混合利用的现象主要出现在中亚东部和中国西北 地区, 其后扩散至欧亚大陆的东西两侧. 上述研究暗示跨大陆东西方文化交流可能始于距今 5 千纪, 在青铜时代 得到强化, 为汉代的丝绸之路的开丵奠定了重要的基础.
\end{abstract}

关键词 新石器-青铜时代, 欧亚大陆,农作物传播, 食物全球化, 跨大陆文化交流

\section{1 引言}

跨大陆尺度的文化和技术交流是推动人类社 会发展进程的主要动力(Kuz'mina, 2008; Zeder, 2008; Anthony, 2010). 在大航海时代(15 17世纪)之前, 跨大
陆的东西方文化交流主要是通过陆路交通开展的, 其 中丝绸之路在汉代以来的欧亚大陆东西方文化交流 中发挥了至关重要的作用. 考古实物证据则显示, 欧 亚大陆的东西方文化交流在史前时代(本文指秦汉(约 2200a BP,“a BP”为距今“1950AD”年代)之前)已经存在,

中文引用格式: $\begin{aligned} & \text { 董广辉, 杨谊时, 韩建业, 王辉, 陈发虎. 2017. 农作物传播视角下的欧亚大陆史前东西方文化交流. 中国科学: 地球科学, 47: 530-543, doi: } \\ & \text { 10.1360/N072016-00279 }\end{aligned}$
英文引用格式: $\begin{aligned} & \text { Dong G H, Yang Y S, Han J Y, Wang H, Chen F H. 2017. Exploring the history of cultural exchange in prehistoric Eurasia from the perspectives of } \\ & \text { crop diffusion and consumption. Science China Earth Sciences, doi: } 10.1007 / \mathrm{s} 11430-016-9037-x\end{aligned}$ 
表现在彩陶、粟㯟、麦类、驯化的牛羊、黄金、青 金石、青铜器、珠料装饰、玉器, 冶金技术和建筑技 术等产品和技术的广泛交流(Sherratt, 2006; Kuz'mina, 2008; Jones等, 2011). 根据不同器物和动植物遗存的 文化特质, 及其出土史前遗址的时空分布, 可以初步 勾勒出欧亚大陆史前东西方文化交流的时间框架, 但 其具体的时空过程未得到充分的讨论.

欧亚大陆史前时代的农作物传播(或称“史前食 物全球化”) 是东西方文化交流的一个重要方面, 近年 来该领域的研究成为国际学术界的热点(张东菊等, 2016; Jones等, 2011, 2016). 全新世早期, 在欧亚大陆 的东西两端各出现了独立的农业起源中心, 农作物小 麦、大麦和家畜羊、牛等驯化于西亚的肥沃新月地 带, 农作物水稻和粟乘则分别驯化于中国的长江和黄 河流域(严文明, 2000; Zeder, 2008; Jones和Liu, 2009; Vigne, 2011). 驯化的农作物和家畜随后从其起源中心 随着人群的扩散, 在欧亚大陆广泛传播, 在距今 4 千纪 (4000 3000a BP), 㯟已传播至中亚、欧洲, 小麦和大麦 成为中国北方广泛利用的农作物(Spengler, 2015; Liu 等, 2016). 上述研究显示在青铜时代早期, 小麦、大 麦和粟㯟已完成跨大陆空间范围的传播, 但由于缺乏 对欧亚大陆史前遗址出土农作物遗存年代的系统总 结和和对比, 东西方农作物 (本文特指西亚农作物小 麦和大麦, 以及东亚农作物粟㯟)传播和汇聚的过程 仍不明晰。

植物考古研究和 ${ }^{14} C$ 测年的积累, 为探讨欧亚大陆 农作物传播和东西方文化交流的历史提供了重要的 依据. 尤其是农作物遗存的直接测年工作, 改变了对 此前农作物传播历史的认识. 如Hunt等(2008)根据欧 洲出土粟㯟遗存遗址的文化属性, 判断这两种中国起 源的农作物在8000 7000a BP已传播至欧亚大陆西端, 然而这些遗址出土的粟㯟遗存直接测年结果都晚于 3500a BP(Matuzeviciute等, 2013). Liu等(2016)对中国 龙山文化(4600 4000a BP)地层出土的小麦遗存直接测 年结果都落在商周时期(约3600 2200a BP), 晚于早期 根据出土小麦遗存的龙山文化层推测的小麦年代(赵 志军, 2004). 因此, 依据农作物遗存出土地层的文化属 性判断年代存在较大的不确定性, 结合出土地层的农 作物遗存的直接测年可为探讨农业发展和传播的历史 提供可靠证据. 人骨碳氮同位素分析则为从食物消费 角度探讨古人类对食物资源的利用提供了有效途径,
小麦和大麦为 $\mathrm{C}_{3}$ 作物, 而粟㯟是 $\mathrm{C}_{4}$ 作物, 碳同位素值 差异显著. 结合植物考古证据和人骨碳同位素值, 可 以有效追踪古人类摄食植物类食物的结构(Lee-Thorp, 2008). 本文通过总结和对比欧亚大陆史前遗址出土麦 类作物(本文特指小麦和大麦)和粟㯟遗存的直接测年 数据, 以及人骨碳同位素数据, 梳理史前时代东亚起 源的农作物粟㯟和西亚起源的农作物小麦和大麦在 欧亚大陆传播和交汇的时空过程，从农作物传播和利 用的视角探讨欧亚大陆史前东西方文化交流的历史.

\section{2 农作物传播记录的史前东西方文化传播 和交汇的过程}

农业起源是人类演化历史中最为重大的变革之 一, 在 $10000 \mathrm{a}$ BP左右, 在西亚的肥沃新月形地带和中 国的黄河流域, 分别出现了麦类作物和粟㯟作物的驯 化(Zeder, 2008; Riehl等, 2013; Lu等, 2009; Zhao, 2011), 是最早的农业起源中心. 人类在经历了旧石器时代数 百万年的迁徙和狩猎采集的生活方式后, 开始逐步走 向定居, 并依靠种植农作物和饲养家畜获取稳定的食 物来源. 这种转变促使欧亚大陆人口在农业起源后快 速增长并向外扩张 (Gignoux等, 2011), 农作物也随着 新石器人群的扩张从其驯化中心向外扩散, 拉开史前 跨大陆农作物传播的序幕. 欧亚大陆史前农作物传播 是文化交流的一个方面, 是观察史前时代东西方文化 交流过程的重要窗口. 根据欧亚大陆史前遗址植物考 古和农作物遗存直接测年结果, 以及人骨碳同位素值 的时空变化(图1和2), 可以将东西方农作物的传播和 交汇过程分为 3 个主要阶段: (1) 10500 4500a BP, 东西 方农作物交汇前的传播与扩散; (2) 4500 3500a BP, 东 西方农作物在中亚东部和中国西北地区的交汇; (3) 3500 2200a BP, 东西方农作物的混合利用范围扩散至 欧亚大陆东西两端.

\section{1 欧亚大陆史前时代东西方农作物交汇前的传 播与扩散}

根据植物考古和测年结果, 小麦和大麦最早在前 陶新石器 B期(PPNB, 10500 9050a BP)驯化于西亚的 黎凡特、安那托利亚和扎格罗斯山的山前地带(Zeder, 2008; Riehl等, 2013), 其中土耳其Nevali Gori遗址麦类 作物遗存直接测年结果为10557 10259a BP(Lösch等, 


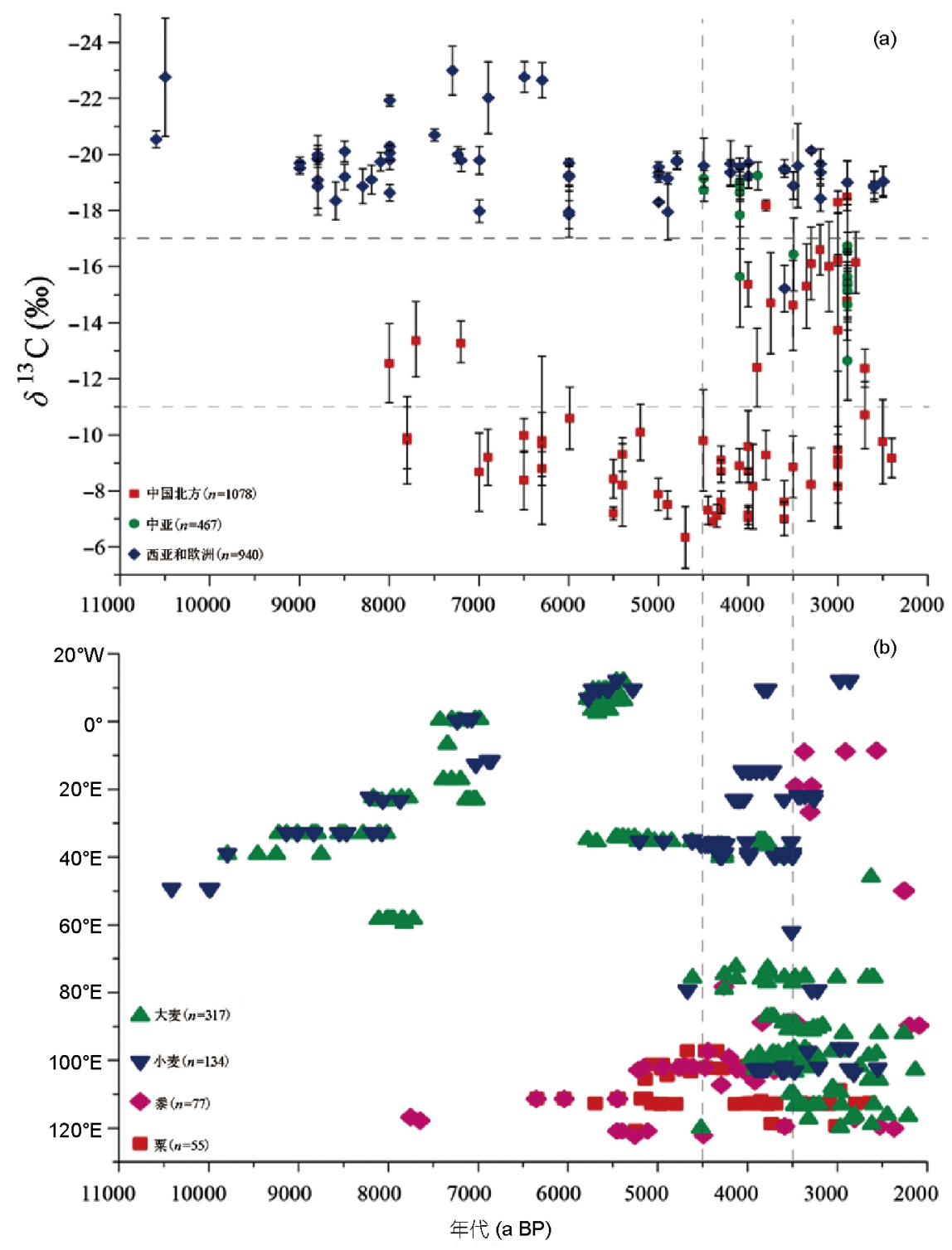

图 1 欧亚大陆新石器-青铜时代遗址人骨碳同位素变化(a)和农作物遗存年代随经度的变化(b)

2006), 叙利亚 Tell Abu Hureyra遗址炭化小麦和大 麦直接测年结果为 10117 9021a BP(Moore, 1992). 10000 9000BP麦类作物已遍及新月形地带, 随后逐 渐向北传播到安纳托利亚高原东部和小亚细亚地区 (Zohary等, 2012). 前陶新石器C期(PPNC, 9050 8450a $\mathrm{BP})$, 近东地区新石器文化得到了快速发展, 具备了定 居、农作物种植、动物驯养和陶器生产等新石器时 代标志性因素(Kuijt和Goring-Morris, 2002), 推动了文 化向周边地区的扩张, 带动了麦类作物向欧洲和中亚 地区的传播(Zohary等, 2012).
麦类作物在9000 8500a BP传播至东南欧地区， 已知欧洲最早的麦类作物遗存出土于希腊和克里 特岛(Perlès, 2001), Franchthi洞穴遗址的农作物种子 作物遗存直接测年结果为8845 8692a BP(Perlès 等, 2013), 8500a BP前麦类作物已扩散至东南欧地区全 境(Greenfield等, 2014). 麦类农业在欧洲东南部发展起 来以后, 呈波浪式向西北方向传播, 8000 7000a BP向 北传播至欧洲中部以德国和奥地利为中心的、以线 纹陶为特征的文化区(Price等, 2001). 8500 7500a BP, 麦类作物随着印纹陶文化的扩张从巴尔干半岛沿地 


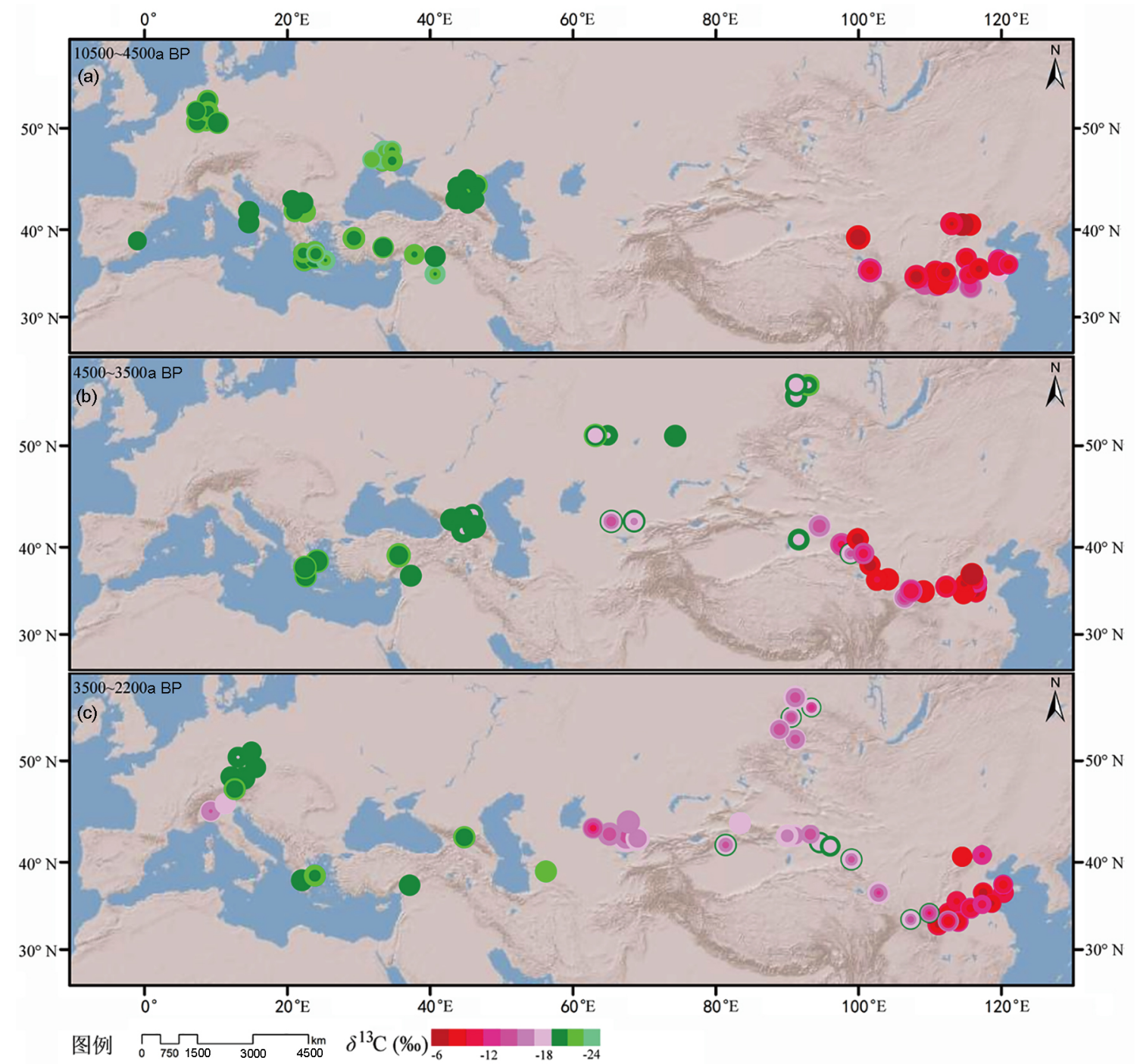

图 2 欧亚大陆新石器-青铜时代遗址出土人骨碳同位素的时空变化

中海沿岸向西传播, 于 $8000 \mathrm{BP}$ 前后传播至意大利、法 国南部、西班牙和葡萄牙地区, 最南到达了西西里岛 (Pinhasi和Pluciennik, 2004). 7000 6000a BP麦类作物向 东扩散至波兰、乌克兰等地区(Zvelebil和Dolukhanov, 1991), 向西北方向扩散到荷兰和德国北部地区(Coward 等, 2008). 6000 5000a BP, 麦类作物传播至大不列颠群 岛(Collard等, 2010), 此后继续向北欧地区传播, 5000a $\mathrm{BP}$ 前后在斯堪的那维亚半岛的挪威和瑞士南部出现由 采集狩猎经济向麦作农业转变的迹象(Robinson, 2003).

8500a BP后麦类作物随文化的扩张开始了向中亚 和东亚地区传播的进程, 于 $8000 \mathrm{a} \mathrm{BP}$ 左右传播至伊朗 西北部和高加索地区(Hovsepyan和Willcox, 2008), 在
里海南部和伊朗东北部戈尔甘地区形成一个麦作农 业生产中心(丹尼和马松, 2002). 戈尔甘地区是连接伊 朗东北部和土库曼斯坦南部的天然通道, 土库曼斯坦 北部山麓新石器早期最具代表性的哲通(Jietun)文化 (8200 7850a BP) 的20多个聚落遗址沿着科彼特达格 山脉北麓分布, 其中哲通遗址出土了中亚最早的麦类 作物遗存, 直接测年在8328 7712a BP(Harris等, 1993). 8000 7500a BP麦类作物继续向东传播至印度次大陆, 该地区较早的麦类遗存主要出土于阿富汗东部和巴勒 斯坦等印度河以西地区, 其中在巴基斯坦的Mehrgarh 遗址(8000 7000a BP)的文化层中出土了小麦和大麦遗 存, 其文化明显受到哲通文化的影响(Costantini, 2008). 
7000 4500a BP在巴基斯坦地区和印度北部麦类作物 被普遍的种植(Tengberg, 1999; Liu等, 2016). 科彼特达 格山脉北麓北部麦类农业在新石器时代晚期到铜石 并用时代Anau文化(7000 5000a BP)时期得到快速的 的发展, 5000a BP前后向东传入了中亚腹地的塔吉克 斯坦(Spengler和Willcox, 2013), 4600a BP前后继续向 东传播至中亚东部哈萨克斯坦七河地区(Spengler等, 2014; Doumani等, 2015).

在欧亚大陆的另一侧, 粟㯟农作物可能最早于 10000a BP左右在中国北方被驯化, 证据主要来源于 东胡林和磁山等遗址的植物大化石和微体化石分析 ( $\mathrm{Lu}$ 等, 2009; Zhao, 2011), 但缺乏粟乘遗存的直接测 年数据支撑. 目前最早的炭化粟㯟种子测年数据来 源于内蒙东部的兴隆沟遗址和山东的月庄遗址, 结 果在7750 7500a BP(图1b)(赵志军, 2008; Crawford等, 2013). 此外, 在黄河流域其他前仰韶时期(8500 7000a BP)文化(裴李岗文化、磁山文化、后李文化和白家 文化等)的遗址中也普遍发现了炭化㯟和粟的种子(秦 岭, 2012), 说明在前仰韶时期驯化㯟和粟已在中国北 方地区得到了普遍利用. 目前粟㯟年代在7500 6500a BP存在缺环(图1b), 该时期是中国北方地区从前仰韶 时代晚期向仰韶时代初期过渡的关键阶段, 中国北方 遗址数量较前仰韶时代没有明显的上升,生业模式发 生明显变化, 由渔猎采集为主转为以粟㯟种植为主(赵 志军, 2014), 可能与7000a BP前后短暂寒冷期有关(韩 建业, 2015).

7000 6000a BP, 仰韶早期文化在黄河中游地区兴 起和发展. 晋南豫西地区仰韶文化早期底董、底董 北、晓坞和南交口遗址植物遗存分析显示, 粟乘遗 存比例占 $84 \%$ (魏兴涛, 2014); 关中地区鱼化寨遗址仰 韶文化早期地层出土炭化粟㯟的比例占 $61 \%$ (赵志军, 2014); 关中东部的白水流域仰韶文化半坡类型晚期睦 王河遗址粟乘的比例占48\%(王欣等, 2015). 上述研究 显示, 中原地区粟乘的出土概率及其所占比重呈上升 趋势(赵志军, 2014), 粟㯟种植在生业模式中的权重增 加, 6500a BP左右以粟㯟种植为主要生产方式的农业 社会已在黄河流域出现(赵志军, 2014).

仰韶中晚期(6000 5000a BP)文化快速发展, 并沿 黄河及其支流广泛扩张, 推动了粟㯟农作物的进一 步扩散. 随着黄河中游仰韶晚期文化的西渐, 粟乘作 物在 5500a BP后, 从关中地区和陇东地区进一步向西
传播(Jia等, 2013), 5200a BP传播至河湟谷地(Chen等, 2015). 5000 4500a BP粟㯟农作物进一步向西扩展至 河西走廊地区(甘肃省文物考古研究所和北京大学文 博学院, 2011; Liu等, 2014). 6000a BP后, 燕辽地区红山 文化时期粟㯟农业的强化(孙永刚和贾金金, 2016), 推动 粟㯟向东北亚地区的快速传播, 在仰韶文化中晚期传 播至西伯利亚东部沿海地区, 并影响到朝鲜半岛(秦岭, 2012), 如: Krounovlta-1(5550 5350a BP)和Zaisanovka7(5500 5000a BP) 遗址出土了粟㯟遗存, 并且以㯟为主 (Sergusheva和 Vostretsov, 2009), 韩国 Pyeonggeodong遗 址出土炭化黍直接测年在5035 4850a BP(Lee, 2011). 仰韶文化中晚期粟向南传播影响到长江流域, 湖南 澧县城头山遗址 $5800 \mathrm{a}$ BP大溪文化中晚期地层发现 炭化粟(Nasu等, 2007), 是目前长江流域最早发现粟 的遗址, 5000 4500a BP 屈家岭文化晚期和石家河文 化早期的石家河古城三房湾和谭家岭遗址也出土了 炭化粟(邓振华等, 2013). 5000a BP后, 在四川盆地 宝墩文化(4900 4000a BP)的遗址中出土了大量粟㯟 遗存(d'Alpoim Guedes等, 2013), 在西藏昌都卡若遗 址中也发现了粟乘遗存, 直接测年结果在 $4700 \sim 4300 \mathrm{a}$ BP(d'Alpoim Guedes等, 2014).

人骨碳同位素分析为探讨粟㯟农业强化的时空 过程提供了有效途径(董广辉等, 2016). 在前仰韶时 期, 中国北方遗址出土的人骨及伴生家养动物猪、狗 骨骼碳同位素值多呈 $\mathrm{C}_{3}$ 信号 $\left(\delta^{13} \mathrm{C}<-17 \%\right)$ 或 $\mathrm{C}_{3}$ 和 $\mathrm{C}_{4}$ 混 合信号 $\left(\delta^{13} \mathrm{C}-17 \sim-11 \%\right.$ ) (如: 小荆山遗址、白家遗址和 大地湾遗址)(Atahan等, 2011; Barton等, 2009), 说明尽 管粟乘种植已经出现,其仅为辅助生业模式, 渔猎采集 仍为主要生业模式. 仅有内蒙古东部的兴隆洼和兴隆 沟遗址出土的人骨呈现 $\mathrm{C}_{4}$ 信号 $\left(\delta^{13} \mathrm{C}>-11 \%\right.$ ) (图1a). 兴 隆沟遗址粟乘占全部植物遗存的 $50 \%$, 且出土的炭化 㯟直接测年在7670 7610a BP, 是目前有直接测年数据 支撑的最早的乘(Zhao, 2011), 显示内蒙东部很可能是 最早的以粟㯟农业种植为主要经济方式的中心之一. 仰韶文化早期, 史家、鱼化寨、姜寨和瓦窑沟遗址的 人骨同位素则呈现 $\mathrm{C}_{4}$ 信号(张雪莲等, 2010 ), 结合植物 考古证据, 显示以粟乘种植为特点的北方原始旱作农 业已经成为中国北方地区仰韶文化分布范围内的主 要生产方式. 5000 4500a BP中国北方(陕豫晋邻境地 区、山东及邻省一部分地区、以长城地带为中心的 北方地区)遗址出土的人骨碳同位素整体呈现偏 $\mathrm{C}_{4}$ 的 
特征, 且有偏重趋势(Lanehart等, 2011; 图 1a), 说明粟 㯟种植在生业模式中的重要性进一步增加, 与植物考 古的结果是一致的.

西亚和中亚地区10500 4500a BP遗址出土人骨的 碳同位素值则全部呈现 $\mathrm{C}_{3}$ 信号(图1a和2), 由于自然界 植物多为 $\mathrm{C}_{3}$ 植物, 无法直接据此推断人类食用了大量 麦类作物, 需要植物遗存分析进行对比验证. 在近东 地区的 Çatalhöyük遗址(9500 8500a BP)和Aktopraklik 遗址(8400 7800a BP), 人骨碳同位素明显呈现 $C_{3}$ 信号 (Richards等, 2003; Budd等, 2013), 其中在Çatalhöyük遗 址发现了大量的大麦、小麦遗存, 其出土概率在 $54 \%$, Aktopraklik遗址发现了大量农作物遗存, 包括大麦、 小麦、燕麦和踠豆等 $\mathrm{C}_{3}$ 作物(Fairbairn等, 2002; Karul 和Avci, 2011). 这个案例暗示, 欧洲、西亚和中亚地区 史前遗址出土人骨的碳同位素值可能也可用于指示古 人类对麦类作物的摄食情况. 在 $4500 \mathrm{a} B \mathrm{BP}$ 前, 在这些 地区都未出现人类摄食 $\mathrm{C}_{4}$ 食物的信号, 也没有粟㯟直 接测年数据, 在东亚地区没有出现麦类作物的直接测 年结果早于 $4500 \mathrm{a}$ BP. 上述结果显示, 尽管10500 4500a $\mathrm{BP}$ 东西方农作物在欧亚大陆两侧广泛传播, 但并未发 生交汇的现象.

\section{2 东西方农作物在中亚东部和中国西北地区的 交汇}

4500 3500a BP, 随着生产技术的进步和人群流动 的辅助性工具 (马和车)的传播, 欧亚大陆人群长距离 迁徙和流动的强度显著增加, 距今 4 千纪上半叶跨大陆 的文化交流达到了一个高峰(Kuz'mina, 2008; Anthony, 2010), 带动了东西方农作物在中国西北和中亚东部地 区的交汇和混合利用.

尽管麦类作物在 $8000 \mathrm{a}$ BP前后已传播至中亚西部 土库曼斯坦南部山麓地区, 其向中亚腹地和东部地区 的传播进程非常缓慢, 迟至距今 5 千纪初才沿着“亚洲 内陆山地走廊”继续向东进入塔吉克斯坦和哈萨克斯 坦等地区(Spengler和Willcox, 2013; Spengler等, 2014). 在哈萨克斯坦东部青铜时代游牧营地遗址(Tasbas遗址 和Begash遗址)出土了大麦、小麦和㯟遗存(Spengler 等, 2014; Doumani等, 2015), Tasbas遗址1阶段地层出 土麦类遗存直接测年在 4565 4418a BP(Doumani 等, 2015), 说明至少在 4600a BP前后麦类作物已传播至中 亚东部, 此后继续向东传播至东亚地区.
中国境内有直接测年数据支撑的最早小麦遗存出 土于山东省赵家庄龙山文化遗址, 年代为4450 4220a BP(靳桂云等, 2011), 显示4450a BP左右麦类作物可 能已传播至欧亚大陆东端, 为认识小麦早期在中国 传播的过程提供了重要的线索. 然而, Liu等(2016)对 山东地区东盘和教场铺龙山文化遗址出土的小麦遗 存直接测年, 结果分布在2850 2073a BP, 明显晚于龙 山时代, 显示探讨麦类作物在山东地区的早期利用 问题仍需开展更细致的工作. 根据已有的测年数据, 中国早期的小麦和大麦遗存多出土于中国西北地区， 尤其是河西走廊及其周边地区的新石器晚期-青铜时 代早期遗址. 例如, 火石梁遗址(4084 3824a BP)和缸 缸洼遗址(3974 3710a BP)(Dodson等, 2013)、西城驿 遗址(3972 3848a BP)(张雪莲等, 2015a; Liu等, 2016) 和金蝉口遗址(3976 3846a BP)(Chen等, 2015)等. 新 疆地区的早期小麦遗存多出土于南疆地区,包括小 河墓地(3707 3478a BP)(Flad等, 2010)、古墓沟墓地 (3834 3695a BP)(Zhang等, 2015; Liu等, 2016)和新塔 拉遗址(3921 3580a BP)(Zhao等, 2013)等, 晚于河西走 廊中部地区, 暗示麦类作物可能通过欧亚草原向东传 播, 沿黑河南下至河西走廊中部, 再向两侧传播, 西至 新疆东部和南部, 东达黄河流域. 然而小麦和大麦史 前时代传入东亚的过程和路线是备受关注且存在明 显争议的科学问题, 仍需开展更多细致的植物考古和 测年工作加以解决.

粟㯟可能在5000 4500a BP 随马家窑文化的西渐 传入河西走廊中部地区 (甘肃省文物考古研究所和北 京大学文博学院, 2011; Liu等, 2014), 随后沿丝绸之路 和欧亚草原南北两条路线继续向新疆和中亚东部传播. 在新疆南部的小河墓地和新塔拉遗址都出土了乘的遗 存, 显示在3800a BP左右乘已传播至哈密和罗布泊地 区(Zhao等, 2013), 很可能是受西城驿文化(4000 3700a BP)和四坝文化(3700 3400a BP)西渐的影响(李水城, 2009; Dodson等, 2013). 秘在4400BP左右传播至中亚 东部的哈萨克斯坦(Spengler等, 2014), Begash遗址炭 化㯟直接测年结果在4410 4103a BP, 该遗址是目前最 早同时出土麦类和㯟遗存的遗址, 说明至少在 $4400 \mathrm{a}$ BP东西方农作物已在中亚东部地区交汇. 4000 3500a $\mathrm{BP}$, 随着跨大陆文化互动强度的增加, 农作物㯟的利用 进一步影响到了中亚东部地区, 在Tasbas遗址2a阶段 (4200 3500a BP)(Doumani等, 2015), 阿富汗Shortughai 
遗址1阶段 (4000 3500a BP)(Willcox, 1991), 巴基斯坦 Harappan文化晚期遗址(4000 3600a BP) 出土了炭化㯟 (Goyal等, 2013), 显示该阶段㯟在中亚东部及其周边 地区得到较广泛的利用.

4500 4000a BP, 中国西北和中亚东部地区遗址出 土人骨的碳同位素值仍然分别呈现 $\mathrm{C}_{4}$ 信号和 $\mathrm{C}_{3}$ 信号(图 1a), 说明尽管该阶段已出现了东西方农作物的交汇, 但 融合强度很低. 4000 3500a BP, 在中亚地区Bestamak 遗址(4000 3600a BP)、Lisakovsk遗址(3860 3700a BP) 和中国西北火烧沟遗址(3870 3634a BP)和磨沟墓地 (3684 3076a BP) 出土的人骨碳同位素值已呈现 $\mathrm{C}_{3}$ 和 $\mathrm{C}_{4}$ 混合信号, 显示人类同时摄食了大量的 $\mathrm{C}_{3}$ 和 $\mathrm{C}_{4}$ 类食 物, 植物考古证据显示很可能是麦类和㯟作物(Miller 等, 2014; Liu等, 2014). 在河西走廊西部的干骨崖墓 地, 人骨碳同位素值呈现偏 $\mathrm{C}_{3}$ 信号, 暗示该遗址先民在 3700 3200a BP可能主要摄食麦类作物 (Liu等, 2014). 在新疆小河墓地和新塔拉遗址都同时出土了麦类和 㯟作物遗存(Zhao等, 2013), 小河墓地人骨古DNA研究 显示该遗址先民存在欧罗巴和蒙古人群的基因混合 信号(Li等, 2010). 这些证据都显示, 4000 3500a BP出 现了强度较高的跨大陆文化互动和基因交流, 但范围 主要集中在中国西北和中亚东部地区(图2b).

\section{3 东西方农作物在欧亚大陆东西全境的传播与 融合}

3500 2200a BP, 欧亚大陆跨大陆文化交流的强度 不断增强, 特别是 $3000 \mathrm{a}$ BP以后的早期铁器时代, 欧亚 草原游牧民族(斯基泰文化)快速的兴起, 促使欧亚大 陆东西方文化交流的空间和强度达到空前的水平, 为 丝绸之路的开通奠定了基础.

$3500 \mathrm{a}$ BP后, 麦类作物在中国北方种植的范围出 现了快速扩展. 在青藏高原东北部, 大麦因其耐高寒环 境的特性, 取代粟乘成为该地区史前人类利用的最重 要的农作物(Dong等, 2016), 并促使人类永久定居到青 藏高原高海拔地区(Chen等, 2015). 麦类作物沿青藏高 原东缘继续向南传播至云南和高原腹地的河谷地带, 在这些地区的多个青铜时代遗址中同时出土了麦类和 粟乘作物遗存, 麦类遗存直接测年结果在3600 2000a BP, 如: 海门口遗址 3 期(3100 2500a BP)、卡若遗址 (3614 2997a BP)、昌果沟遗址(3235 3237a BP)、邦 嘎遗址(3002 2185a BP)、阿梢垴遗址(3500 2000a BP)
等(Liu等, 2016). 麦类作物沿黄河及其支流河谷继续 东传(图1b), 在周原遗址(3138 2922a BP)、南沙遗址 (3592 3449a BP)、东高村遗址(3065 2885a BP)、偃师 商城(3441 3353a BP)、王城岗遗址(3556 3378a BP)、 费窑南遗址(3033 2876a BP)、刘家庄遗址(3390 3239a BP)、大辛庄遗址(3055 2868a BP)等(Dodson等, 2013; Liu等, 2016)商周遗址出土的小麦遗存年代与文化属 性有很好的对应,说明麦类作物在商周时期已大规模 种植(Dodson等, 2013; Liu等, 2016). 此外, 3500 2200a $\mathrm{BP}$ 新疆地区的麦类作物遗存也大量的发现(Dodson等, 2013), 在新疆开展植物考古的焉不拉克文化和苏贝希 文化遗址中, 普遍出土大麦和小麦遗存(Jiang等, 2013; Dodson等, 2013), 具有代表性的洋海墓地墓室随葬有 小麦和大麦(蒋洪恩等, 2007), 说明麦类作物是该地区 青铜时代晚期-铁器时代人类种植的主要农作物.

3500 2200Ba BP㯟进一步向西传播, 3500 3000a BP传到中亚西部，在土库曼斯坦的 Tahirbai Depe 遗址 (3000 2600a BP) 和 Dam Dam Cheshme 遗址 (3200 2800a BP) 都出土了乘遗存 (Spengler, 2015). Matuzeviciute 等 (2013) 对欧洲遗址出土的炭化㯟 直接测年结果显示, 3500a BP后㯟传播至欧洲, 证据来自欧洲东部罗马尼亚的 Măgura-Buduiasca 遗址(3380 3241a BP), 欧洲中部匈牙利和德国的 Bruchenbrücken/Friedberg 遗址 (3453 3270a BP)、 Fechenheim/Frankfurt 遗址 (3004 2804a BP) 和 Goddelau/Riedstadt遗址(2729 2381a BP). 秘传播到黑海北岸 地区可能晚至铁器时代的Scythian-Sarmatian(萨夫罗 马泰-萨尔马泰文化)时期(2700 2400a BP), 在黑海北 部乌克兰的Zanovsko遗址出土的炭化㯟遗存直接测 年结果为2354 2159a BP(Matuzeviciute等, 2012).

人骨碳同位素证据显示3500 2200a BP在欧亚大 陆不同地区, 尤其是中亚和中国西北地区, 东西方农 作物的融合利用强度显著增加, 表现在出土人骨碳 同位素值呈现 $\mathrm{C}_{3}$ 和 $\mathrm{C}_{4}$ 混合信号的遗址数量显著增加 (图1a), 分布的范围显著扩张(图2c). 在中国西北甘青 地区, 3600a BP左右人骨碳同位素值出现由 $\mathrm{C}_{4}$ 信号向 $\mathrm{C}_{3}$ 和 $\mathrm{C}_{4}$ 混合信号的转变, 反映出人类从单一种植粟㯟 向对麦类和粟㯟作物的混合利用的方式转变 $(\mathrm{Ma}$ 等, 2016). 在陇西黄土高原的西山遗址, 2700 2400a BP的 先民摄食了大量的 $\mathrm{C}_{3}$ 作物(Ma等, 2016). 然而, 在中原 地区, 多个商周时期墓地人骨同位素显示人类摄食结 
构仍以 $\mathrm{C}_{4}$ 作物为主, 很少摄食 $\mathrm{C}_{3}$ 作物 (张雪莲等, 2003), 直到战国-西汉时期(2475 2000a BP) 该地区人类才同 时摄食大量 $\mathrm{C}_{3}$ 和 $\mathrm{C}_{4}$ 作物 (侯亮亮等, 2012), 麦类作物很 可能占有重要地位, 如: 申明铺遗址出土的植物遗存 以小麦居首, 大豆次之(侯亮亮等, 2012). 两汉时期西 安和洛阳墓葬出土陶仓都书有“大麦”和“小麦”, 部分 墓葬出土小麦遗存.

中亚地区青铜时代晚期-铁器时代(3500 2500a $\mathrm{BP}$ )遗址出土的人骨碳同位素值大多呈现 $\mathrm{C}_{3}$ 和 $\mathrm{C}_{4}$ 混 合信号(图2c, Matuzeviciute等, 2015). 青铜时代中晚 期(4000 3000a BP)中亚北部的广阔地区统一进入了 游牧文化时代, 有学者称为“安德罗诺沃文化综合体 (Andronovo Cultural Complex)", 该地区遗址出土人骨 的碳同位素值显示从青铜时代中晚期到早期铁器时代 (4000 2500a BP) 人类主要摄食 $\mathrm{C}_{3}$ 作物, 辅以很少量的 $\mathrm{C}_{4}$ 作物(Miller等, 2014). 中亚南部农业部落青铜时代 晚期(3500 3000a BP) 以麦类农业种植为主, 铁器时代 (3000 2500a BP) 乘作物的摄入开始增加, 㯟和麦类混 合农业在中亚南部建立(Matuzeviciute等, 2015). 欧洲 希腊地区青铜时代(5500 3000a BP)遗址出土人骨碳同 位素绝大多数呈现 $\mathrm{C}_{3}$ 信号(Petroutsa和Manolis, 2010), 但意大利Olmo di Nogara遗址(3600 3200a BP)出土人 骨碳同位素值呈现 $\mathrm{C}_{3}$ 和 $\mathrm{C}_{4}$ 混合信号(Tafuri等, 2009), 暗 示在3500a BP粟㯟传入欧洲后, 部分地区先民将粟㯟 作为重要的食物来源.

\section{3 多重证据记录的欧亚大陆史前东西方文 化元素传播和互动过程}

史前欧亚大陆东西文化的扩散和交流留下多方 面的印记, 不仅体现在实物遗存方面, 如: 具有东方文 化特征的彩陶、粟㯟和西方文化特征的青铜器、权 杖头、麦类作物和家畜羊等, 还表现在技术和观念上, 如: 土坏建筑技术、金属铸造工艺和珠料制作技术, 动物纹样装饰艺术等(Sherratt, 2006; Kuz'mina, 2008; Roberts等, 2009; Jones等, 2011, 2016). 通过对具有明 确东方或西方文化特质的多重遗存证据的分析, 及其 与东西方农作物时空分布的对比, 可以更全面地认识 史前时代东西方文化交流的过程, 以及目前该领域研 究存在的问题.

有学者认为起源于西亚的青铜器(或青铜冶炼技
术)、羊和小麦是以“文化包裹”的形式传播,同时传 入东亚地区(Zhao, 2009), 但目前的研究证据与该观点 存在出入. 羊在 $10000 \mathrm{a}$ BP之前驯化于西亚的伊朗、 土耳其、叙利亚等地区(Hongo等, 2009), 10000a BP 后分布于扎格罗斯山脉另一个谱系的山羊也被驯化 (Zeder和Hesse, 2000), 之后随着人群的扩散向周边地 区传播. 8000 7000a BP向东传播到中亚的科彼特达 格山脉北麓(Harris等, 1993), 5000 4000a BP传入中亚 的东部地区 (Lightfoot等, 2015). 目前的动物考古和羊 骨古DNA分析认为驯化的羊在 5600 4000a BP传入中 国西北地区(Dodson等, 2014), 如: 在甘肃西山坪遗址 M5(5600 5000a BP)出土了羊的下领骨(袁靖, 2015), 青 海民和核桃庄墓地马家窑类型墓葬(5300 4600a BP) 出土了完整羊骨架(袁靖, 2015), 在陕西仰韶文化晚期 (5500 5000a BP) 零口村遗址和半坡遗址也出土了羊 的骨骼. 但对于这些遗址出土的羊骨是否确定为驯化 羊的遗存,学术界尚存在争议(袁靖, 2015).

9000 7000a BP合金铜冶炼技术最早出现在西亚 的新月沃土地带, 7000a BP后铜冶炼技术在土耳其 东部和安纳托里亚南部区已得到普遍利用(Wertime, 1973), 6000a BP前后在黎凡特地区出现了一个重要的 冶炼中心(Golden, 2016). 随着近东地区文化的扩张, 铜 冶炼技术开始向欧洲、中亚和东亚地区传播(Roberts 等, 2009). 5500 5000a BP西亚美索不达米亚地区出现 了青铜冶炼技术(De Ryck等, 2005; Roberts等, 2009), 5000 4000a BP青铜冶炼技术传入中亚的哈萨克斯坦 地区, 在 $4500 \mathrm{a}$ BP前后冶金技术传播至哈萨克斯坦北 部和乌拉尔山南部地区并发展成冶金中心(Chernykh, 1992), 4000a BP前后冶金技术继续向东发展传播至中 国(Linduff和Mei, 2009). 然而, 甘肃马家窑文化林家遗 址(5000 4600a BP) 出土了青铜刀 1 件和残留的铜渣数 块(李水城, 2009), 显示青铜器及治铜技术传入中国西 北地区的时代可能更早. 但目前仅为孤证, 尚需更多 证据进行检验.

其他具有西亚文化特质的文化元素还有土坏建 筑技术、权杖头和动物纹装饰等. 土坏是人类发明的 最早建筑材料之一, $11000 \mathrm{a}$ BP前后土坏最早出现在美 索不达米亚地区(Oates, 1990), 其中约旦河谷Dhra'遗 址(10800 9000a BP) 出土了目前最早的土坏遗存(Kuijt 和Mahasneh, 1998). 土坯作为建筑材料, 为推动西亚 地区早期城市和大型定居聚落的出现起到了重要的 
作用(丹尼和马松, 2002). 8000a BP前后土坏东传至伊 朗北部(丹尼和马松, 2002), 8000 7000a BP中亚西部 科彼特达格山脉北麓的哲通文化发现的聚落遗址发 现了土坏房址(Harris等, 1996). 5000 4000a BP土坏建 筑技术出现在中亚东部的塔吉克斯坦和哈萨克斯坦 (Doumani等, 2015; Spengler和Willcox, 2013). 目前, 中 国湖北屈家岭文化(5000 4600a BP)门板湾遗址首次 发现中国已知年代最早的土坏房屋建筑遗迹. 然而, 西方的土坏为湿泥模制, 而中国内地为夯制而成, 二 者有别, 尚无确丵证据显示土坏建筑技术在 $4500 \mathrm{a}$ BP 之前传入中国北方(韩建业, 2015).

权杖头是西亚地区象征权利的重要器物之一. 目 前世界上最早的权杖是出土于以色列 Sha'ar Hagolan 遗址(8500 7800a BP)的石质权杖头(Rosenberg, 2010), 在近东地区新石器晚期-青铜时代早期(7000 5000a BP)出土了大量的石头和青铜制作的权杖头(Moorey, 1988). 权杖 7000 5000a BP传入欧洲, 铜石并用时代青铜时代早期(6000 5000a BP) 由伊朗高原北部进入 中亚, 继而向东影响到东亚地区(Kirčo, 1988). 中国最 早的权杖头是发现于甘肃宁县宁家庄遗址的彩绘权 杖头, 其时代在庙底沟类型时期 $(5900 \sim 5500 \mathrm{a}$ BP), 在东 北赤峰地区红山文化晚期到小河沿文化(5000 4500a BP)时期的遗址出土了 7 件权杖头(李水城, 2010), 暗示 西亚文化元素可能在5500 4500a BP已影响到东亚地 区.

史前时代东方文化元素向西的扩张, 主要表现为 起源于中国黄河流域的彩陶不断西渐的过程. 彩陶最 早出土于大地湾一期文化(7800 7200a BP)(甘肃省文 物考古研究所, 2006), 至仰韶文化零口类型、半坡类 型时期(7000 6000a BP), 彩陶在黄河流域中游得到快 速的发展, 仰韶文化庙底沟类型时期彩陶已在中国 北方地区广泛利用(韩建业, 2013)。约5500、5000、 4000和 3300a BP彩陶经历了 4次西渐的过程(韩建业, 2013), 5500 5000a BP黄河中上游地区的仰韶文化彩 陶已向西传播至青海东北部. 马家窑文化时期彩陶大 规模向西扩张, 主要沿甘肃中部-河湟谷地-河西走廊 扩散, 5000 4500a BP传播至河西走廊中部地区(韩建 业, 2013)

西亚最早的彩陶出土于西亚两河流域北部的Jarmo 有陶文化(8100 7500a BP)和Hassuna文化(7980 7280a $\mathrm{BP})$ 的遗址, 多见动物纹饰和几何纹饰, 但在 $7000 \mathrm{a}$
BP前后西亚彩陶文化衰落(LeBlanc和Watson, 1973). 8000 6200a BP, 在伊朗北部的Ubaidian文化和土库曼 斯坦Jeitun文化的遗址出土了彩陶遗存, 彩绘以动物 纹饰和几何形纹饰为主(Caldwell, 1968; 丹尼和马松, 2002), 尚无与中国黄河流域的彩陶有直接联系的迹 象. 6800 5000a BP东南欧一带的Tripolje-Cucuteni文化 (6800 5000a BP)彩陶非常兴盛(King和Underhill, 2002), 中亚的Namazga I III期文化(6200 5000a BP)和Anau文 化(7000 5000a BP)也发现了大量的彩陶(Kohl, 1981), 盛行连续锯齿纹组成的菱形、十字形图案和具象性 的动物纹. 该时期中国黄河流域的仰韶文化庙底沟类 型的彩陶最为发达, 这几个区域都发现了花瓣纹彩陶, 但是他们之间是否有实际联系还不能确定, 但是中国 马家窑文化马家窑类型出现少量的连续性锯齿状纹 饰, 半山类型(4600 4300a BP)盛行锯齿状纹饰, 说明 至少在半山类型的锯齿纹可能受到中亚的影响.

上述证据显示, 在 $4500 \mathrm{a}$ BP之前, 欧洲、西亚和中 亚地区仍无确切的东方文化元素影响的证据. 然而, 具有西方文化特质的元素可能已经影响到了中国的 北方地区, 尤其是权杖头、羊和青铜器及其冶炼技术 遗存已在中国内蒙东部和黄河中上游地区出现. 尽管 这些证据的时代及其来源(例如, 是否存在本土起源) 尚存在较大的不确定性, 需要更多的研究工作进行对 比检验, 但其显示欧亚大陆东西方文化交流可能早于 4500a BP, 提示以植物考古和测年工作探讨史前跨大 陆的文化交流问题,仍需积累更多证据.

4500 3500a BP是东西方农作物在中亚东部和中 国西北地区交汇融合的时期, 这也得到了其他考古 证据的支持. 4000a BP前后马家窑文化马厂类型晚期 西渐至新疆东部的哈密地区, 4000 3400a BP河西走 廊西城驿-四坝文化再次西进(李水城, 2009), 对新疆 东部地区的青铜文化产生重要影响, 形成盛行彩陶的 哈密天山北路文化(3900 3300a BP)和焉不拉克文化 (3300 2600a BP)(韩建业, 2013).

西亚文化元素在青铜时代早期对中国西北地 区的影响则更为明显。在西北甘青地区齐家文化 (4200 3600a BP) 的大河庄、秦魏家、师赵村等遗 址出土了驯化羊的骨骼(袁靖, 2015), 西城驿文化 (4000 3700a BP)西城驿遗址和四坝文化(3700 3400a BP)东灰山墓地也出土了羊的骨骼(张雪莲等, 2015b). 在中原地区龙山时代晚期的 4 个遗址(陶寺遗址、王 
城岗遗址、瓦店遗址、白营遗址)发现了家养绵羊的 骨骼遗存(袁靖, 2015), 在新疆地区的早期青铜遗址中 也发现了家羊的骨骼. 青铜器及其冶炼技术约4000a $\mathrm{BP}$ 传入中国西北地区, 随后在河西走廊和新疆东部形 成了中国最早的冶金中心(李水城, 2009), 4000 3400a $\mathrm{BP}$ 河西走廊高强度的治金活动使得文化层土壤的铜 元素含量显著增加(Yang等, 2016). 虽然有学者认为河 西走廊的冶金存在独立起源的可能(李水城, 2009; 陈 国科等, 2014), 但从早期冶金技术和出土铜器类型判 断,明显受到西亚青铜冶炼技术东传的影响.

4000 3500a BP, 河西走廊西城驿-四坝文化的遗 址出土了大量的玉石权杖头和青铜铸造的权杖头(陈 国科等, 2014), 在黄土高原发现了齐家晚期-西周时期 的权杖头, 在新疆地区的青铜时代遗址也普遍发现了 权杖头(李水城, 2010). 此外, 在河西走廊西城驿-四坝 文化的西城驿遗址发现了土坏房址(陈国科等, 2014), 新疆早期青铜遗址发现土坏建筑和土坏墓, 很可能是 受到欧亚草原文化(阿凡纳谢沃文化、奥库涅夫文化) 的东进和南下扩张的影响 (不排除通过中亚绿洲文化 东进的可能). 上述证据都显示在早期跨大陆文化互 动过程中, 河西走廊地区是最早出现东西方文化元素 碰撞融合的关键地区之一, 与植物考古和人骨碳同位 素分析结果是一致的.

商周时期, 东西方文化元素的融合扩展至欧亚大 陆的东西两侧. 青铜时代晚期到铁器时代(3300 2200a $\mathrm{BP}$ )彩陶几乎遍布新疆全境(韩建业, 2013), 彩陶继续 向西扩张, 3500a BP后影响到中亚费尔干纳盆地的楚 斯特文化(3500 2700a BP)(韩建业, 2013). 3000BP以 后欧亚草原大部分地区受到游牧民族文化的影响, 改 变了以农业为主的生活方式, 牛、马、羊被大量的养 殖, 半农半牧或游牧的生活方式出现在中国西北和长 城沿线地带. 青铜时代晚期和铁器时代(3300 2400a BP)新疆大部分墓葬出土了羊的骨骼(安家瑗和袁靖, 1998), 河西走廊地区的沙井文化(2800 2400a BP)和 骟马文化(3000 2400a BP), 以及青藏高原东北部和陇 西黄土高原青铜时代诸文化(3600 2300a BP)的遗址 也大量出土羊和牛的骨骼(袁靖, 2015), 明显受到欧 亚草原游牧文化的影响. 此外, 长城沿线从宁夏的杨 郎文化(2700 2300a BP) 到内蒙古东部桃红巴拉文化 (2700 2300a BP) 的遗址大量随葬和出土羊、马、牛 的骨骼(乌恩, 2002), 中原地区商周时期以马、牛、羊
随葬和用于祭祀的现象较为普遍(袁靖, 2015), 显示该 时段西方文化元素对中国北方地区的影响明显增强.

3500 3000a BP 欧亚大陆游牧化进程加快, 特别是 3000a BP以后斯基泰文化的兴起与扩张, 留下大量独 特的青铜遗物, 其中以斯基泰三要素(兵器、马具、动 物纹装饰艺术)最具代表性. 新疆地区青铜时代晚期受 到了安德罗诺沃文化(3800 3300a BP) 和卡拉苏克文 化(3500 2800a BP) 的强烈影响, 铁器时代受到斯基泰 文化的影响, 出土了大量的青铜工具、武器和动物装 饰品(Mei和Shell, 1999). 从河西走廊-青藏高原-长城 沿线的草原地带, 青铜时代到铁器时代文化受到了欧 亚草原文化影响, 大量的青铜器都具有草原风格的特 征(陈国科等, 2014; 乌恩, 2002). 治金技术在河西走廊 得到发展之后, 向东影响了甘青地区的齐家文化及青 铜时代诸文化, 对中原商周时期青铜铸造技术和青铜 器也产生了重要的影响(Linduff和Mei, 2009; 李水城, 2009). 同时, 中国北方地区商代-西周时期(3600 2700a BP) 青铜器兴起之后对新疆和俄罗斯米努辛斯克盆地 青铜时代晚期卡拉苏克文化(3500 2800a BP)产生了 重要的影响(杨建华等, 2016).

\section{4 结论}

欧亚大陆史前遗址出土的农作物直接测年数据 和人骨碳同位素分析结果, 为从农作物传播的视角理 解史前欧亚大陆跨大陆文化交流与互动的过程提供 了重要的科学依据. 根据目前的研究进展, 欧亚大陆 史前东西方农作物的传播与交汇可分为 3 个主要阶段:

(1) 10500 4500a BP, 西亚起源的农作物小麦和大 麦已传播至欧洲和中亚的大部分地区, 中国北方起源 的农作物粟㯟则扩散至黄河流域全境和河西走廊地 区，该时段未出现粟㯟和小麦、大麦混合利用的迹象;

(2) 4500 3500a BP, 东西方农作物首先在哈萨克 斯坦汇聚, 该阶段在中亚东部和中国西北地区的一些 遗址出现了同时利用和摄食麦类作物和㯟的特征, 在 其他地区则很少出现, 是跨大陆的东西方文化交流的 早期阶段;

(3) 3500 2200a BP, 粟㯟和麦类作物混合利用的 现象已扩展至欧亚大陆东西两端, 暗示跨大陆的东西 方文化交流的广度和强度达到空前水平, 为此后丝绸 之路的开丵奠定了重要的基础. 上述模式与其他考古 证据勾勒的史前欧亚大陆东西方交流过程基本相符, 
但在东西方文化碰撞的起始时间方面尚存在差异, 是 有待未来多学科团队进行对比研究和探讨的问题.

\section{参考文献}

Crawford G W, 陈雪香, 奕丰实. 2013. 山东济南长清月庄遗址2003 年植物遗存初步分析. 江汉考古, 2: 107-116

安家瑗, 袁靖. 1998. 新疆和静县察吾乎沟口一、三号墓地动物骨 骼研究报告. 考古, 7: 63-68

陈国科, 王辉, 李延祥, 张良仁, 杨月光. 2014. 甘肃张掖市西城驿遗 址. 考古, 7: 3-17

丹尼 $\mathrm{A} \mathrm{H}$, 马松V M. 2002. 中亚文明史(第1卷). 北京: 中国对外翻 译出版公司. 119-176

邓振华, 刘辉, 孟华平. 2013. 湖北天门市石家河古城三房湾和谭家 岭遗址出土植物遗存分析. 考古, 1: 91-99

董广辉, 张山佳, 杨谊时, 陈建徽, 陈发虎. 2016. 中国北方新石器时 代农业强化及对环境的影响. 科学通报, 61: 2913-2925

甘肃省文物考古研究所. 2006. 秦安大地湾: 新石器时代遗址发掘 报告. 北京: 文物出版社. 30-47

甘肃省文物考古研究所, 北京大学考古文博学院. 2011. 河西走廊 史前考古调查报告. 北京: 文物出版社. 427-430

韩建业. 2013. “彩陶之路”与早期中西文化交流. 考古与文物, 1 : 28-37

韩建业. 2015. 早期中国-中国文化圈的形成和发展. 上海: 上海古 籍出版社. 56-263

靳桂云, 王海玉, 燕生东, 刘长江, 兰玉富, 佟佩华. 2011. 山东胶州 赵家庄遗址龙山文化碳化植物遗存研究. 科技考古(第3辑). 北 京: 科学出版社. 36-53

侯亮亮, 王宁, 吕鹏, 胡耀武, 宋国定, 王昌燧. 2012. 申明铺遗址战 国至两汉先民食物结构和农业经济的转变. 中国科学: 地球科 学, 42: 1018-1025

李水城. 2009. 东风西渐: 中国西北史前文化之进程. 北京: 文物出 版社. 200-293

李水城. 2010. 赤峰及周边地区考古所见权杖头及潜在意义源. 见: 红山文化高峰论坛.7-11

蒋洪恩, 李肖, 李承森. 2007. 新疆吐鲁番洋海墓地出土的粮食作物 及其古环境意义. 古地理学报, 9: 551-558

秦岭. 2012. 中国农业起源的植物考古研究与展望, 考古学研究 (九). 北京: 文物出版社. 302-303

孙永刚, 贾金鍂. 2016. 辽西地区红山文化时期生业方式及其相关问 题研究. 辽宁师范大学学报, 39: 129-134

魏兴涛. 2014. 豫西晋西南地区新石器时代植物遗存的发现与初步 研究. 东方考古(11). 北京: 科学出版社. 343-363

王欣, 尚雪, 蒋洪恩, 张鹏程, 王炜林, 王昌燧. 2015. 陕西白水河流 域两处遗址浮选结果初步分析. 考古与文物, 2: 100-104

乌恩. 2002. 欧亚大陆草原早期游牧文化的几点思考. 考古学报, 4:
$437-470$

严文明. 2000. 农业发生与文明起源. 北京: 科学出版社. 50-89 杨建华, 邵会秋, 潘玲. 2016. 欧亚草原东部的金属之路——丝绸之

路与匈奴联盟的孕育过程. 上海: 上海古籍出版社. 133-170 袁靖. 2015. 中国动物考古学. 北京: 文物出版社. 88-175 张东菊, 董广辉, 王辉, 任晓燕, 哈比布, 强明瑞, 陈发虎. 2016. 史 前人类向青藏高原扩散的历史过程和可能驱动机制. 中国科学: 地球科学, 46: 1007-1023

张雪莲, 王金霞, 冼自强, 仇士华. 2003. 古人类食物结构研究. 考 古, 2: $62-75$

张雪莲, 仇士华, 钟建, 赵新平, 孙福喜, 程林泉, 郭永淇, 李新伟, 马 萧林. 2010. 中原地区几处仰韶文化时期考古遗址的人类食物 状况分析. 人类学学报, 29: 197-207

张雪莲, 仇士华, 钟建, 黄晔. 2015a. 放射性碳素测定年代报告(四 一). 考古, 7: 107-109

张雪莲, 张君, 李志鹏, 张良仁, 陈国科, 王鹏. 2015b. 甘肃张掖市西 城驿遗址先民食物状况的初步分析. 考古, 7: 110-120

赵志军. 2004. 两城镇与教场铺龙山时代农业生产特点的对比分析. 东方考古(1). 北京: 科学出版社. 210-224

赵志军. 2008. 小米起源的研究一一植物考古学新资料和生态学分 析. 赤峰学院学报: 汉文哲学社会科学版, S1: 35-38

赵志军. 2014. 中国古代农业的形成过程——浮选出土植物遗存证 据. 第四纪研究, 34: 73-84

Anthony D W. 2010. The Horse, the Wheel, and Language: How BronzeAge Riders from the Eurasian Steppes Shaped the Modern World. Princeton: Princeton University Press. 121-456

Atahan P, Dodson J, Li X Q, Zhou X Y, Hu S M, Chen L, Bertuch F, Grice K. 2011. Early Neolithic diets at Baijia, Wei River valley, China: Stable carbon and nitrogen isotope analysis of human and faunal remains. J Archaeol Sci, 38: 2811-2817

Barton L, Newsome S D, Chen F H, Wang H, Guilderson T P, Bettinger R L. 2009. Agricultural origins and the isotopic identity of domestication in northern China. Proc Natl Acad Sci USA, 106: 5523-5528 Budd C, Lillie M, Alpaslan-Roodenberg S, Karul N, Pinhasi R. 2013. Stable isotope analysis of Neolithic and Chalcolithic populations from Aktopraklık, Northern Anatolia. J Archaeol Sci, 40: 860-867

Caldwell J R. 1968. Pottery and cultural history on the Iranian Plateau. J Near East Stud, 27: 178-183

Chen F H, Dong G H, Zhang D J, Liu X Y, Jia X, An C B, Ma M M, Xie Y W, Barton L, Ren X Y, Zhao Z J, Wu X H, Jones M K. 2015. Agriculture facilitated permanent human occupation of the Tibetan Plateau after 3600 B.P. Science, 347: 248-250

Chernykh E N. 1992. Ancient Metallurgy in the USSR: The Early Metal Age. Cambridge: Cambridge University Press. 98-215

Collard M, Edinborough K, Shennan S, Thomas M G. 2010. Radiocarbon evidence indicates that migrants introduced farming to Britain. $\mathrm{J}$ 
Archaeol Sci, 37: 866-870

Costantini L. 2008. The first farmers in Western Pakistan: The evidence of the Neolithic agropastoral settlement of Mehrgarh. Pragdhara, 18: $167-178$

Coward F, Shennan S, Colledge S, Conolly J, Collard M. 2008. The spread of Neolithic plant economies from the Near East to northwest Europe: A phylogenetic analysis. J Archaeol Sci, 35: 42-56

d'Alpoim Guedes J, Jiang M, He K Y, Wu X H, Jiang Z H. 2013. Site of Baodun yields earliest evidence for the spread of rice and foxtail millet agriculture to south-west China. Antiquity, 87: 758-771

d'Alpoim Guedes J, Lu H L, Li Y X, Spengler R N, Wu X H, Aldenderfer M S. 2014. Moving agriculture onto the Tibetan Plateau: The archaeobotanical evidence. Archaeol Anthropol Sci, 6: 255-269

De Ryck I, Adriaens A, Adams F. 2005. An overview of Mesopotamian bronze metallurgy during the 3rd millennium BC. J Cult Herit, 6: 261-268

Dodson J, Dodson E, Banati R, Li X Q, Atahan P, Hu S M, Middleton R J, Zhou X Y, Sun N. 2014. Oldest directly dated remains of sheep in China. Sci Rep, 4: 7170

Dodson J R, Li X Q, Zhou X Y, Zhao K L, Sun N, Atahan P. 2013. Origin and spread of wheat in China. Quat Sci Rev, 72: 108-111

Dong G, Ren L, Jia X, Liu X, Dong S, Li H, Wang Z, Xiao Y, Chen F. 2016. Chronology and subsistence strategy of Nuomuhong Culture in the Tibetan Plateau. Quat Int, 426: 42-49

Doumani P N, Frachetti M D, Beardmore R, Schmaus T M, Spengler Iii R N, Mar'yashev A N. 2015. Burial ritual, agriculture, and craft production among Bronze Age pastoralists at Tasbas (Kazakhstan). Archaeol Res Asia, 1-2: 17-32

Fairbairn A, Asouti E, Near J, Martinoli D. 2002. Macro-botanical evidence for plant use at Neolithic Çatalhöyük south-central Anatolia, Turkey. Veg Hist Archaeobot, 11: 41-54

Flad R, Li S C, Wu X H, Zhao Z J. 2010. Early wheat in China: Results from new studies at Donghuishan in the Hexi Corridor. Holocene, 20: 955-965

Gignoux C R, Henn B M, Mountain J L. 2011. Rapid, global demographic expansions after the origins of agriculture. Proc Natl Acad Sci USA, 108: 6044-6049

Golden J M. 2016. Dawn of the Metal Age: Technology and Society during the Levantine Chalcolithic. Oxford: Routledge. 8-96

Goyal P, Pokharia A K, Kharakwal J S, Joglekar P, Rawat Y S, Osada T. 2013. Subsistence system, paleoecology, and ${ }^{14} \mathrm{C}$ chronology at kanmer, a Harappan Site in Gujarat, India. Radiocarbon, 55: 141-150

Greenfield H, Greenfield T L, Jezik S. 2014. Subsistence and settlement in the early Neolithic of temperate SE Europe: A view from Blagotin, Serbia. Archaeol Bulgarica, 18: 1-33

Harris D R, Gosden C, Charles M P. 1996. Jeitun: Recent excavations at an early Neolithic site in southern Turkmenistan. Proc Prehist Soc, 62: $423-442$

Harris D R, Masson V M, Berezkin Y E, Charles M P, Gosden C, Hillman G C, Kasparov A K, Korobkova G F, Kurbansakhatov K, Legge A J, Limbrey S. 1993. Investigating early agriculture in Central Asia: New research at Jeitun, Turkmenistan. Antiquity, 67: 324-338

Hongo H, Pearson J, Öksüz B, Ilgezdi G. 2009. The process of ungulate domestication at Çayönü, Southeastern Turkey: A multidisciplinary approach focusing on Bossp. and Cervus elaphus. Anthropozoologica, 44: 63-78

Hovsepyan R, Willcox G. 2008. The earliest finds of cultivated plants in Armenia: Evidence from charred remains and crop processing residues in pisé from the Neolithic settlements of Aratashen and Aknashen. Veg Hist Archaeobot, 1: 63-71

Hunt H V, Vander Linden M, Liu X Y, Matuzeviciute G M, Colledge S, Jones M K. 2008. Millets across Eurasia: Chronology and context of early records of the genera Panicum and Setaria from archaeological sites in the Old World. Veg Hist Archaeobot, 17: 5-20

Jia X, Dong G H, Li H, Brunson K, Chen F H, Ma M M, Wang H, An C B, Zhang K R. 2013. The development of agriculture and its impact on cultural expansion during the late Neolithic in the Western Loess Plateau, China. Holocene, 23: 85-92

Jiang H, Wu Y, Wang H, Ferguson D K, Li C S. 2013. Ancient plant use at the site of Yuergou, Xinjiang, China: Implications from desiccated and charred plant remains. Veg Hist Archaeobot, 22: 129-140

Jones M K, Liu X Y. 2009. Origins of agriculture in East Asia. Science, 324: $730-731$

Jones M K, Hunt H, Kneale C J, Lightfoot E, Lister D, Liu X Y, Matuzeviciute G M. 2016. Food globalisation in prehistory: The agrarian foundations of an interconnected continent. J Br Acad, 4: $73-87$

Jones M K, Hunt H, Lightfoot E, Lister D, Liu X Y, Matuzeviciute G M. 2011. Food globalization in prehistory. World Archaeol, 43: 665-675

Karul N, Avci M B. 2011. Neolithic communities in the eastern Marmara region: Aktopraklik. Anatolica, 37: 1-15

King R, Underhill P A. 2002. Congruent distribution of Neolithic painted pottery and ceramic figurines with Y-chromosome lineages. Antiquity, 76: 707-714

Kirčo L B. 1988. The beginning of the Early bronze Age in Southern Turkmenia on the basis of Altyn-depe Materials. East and West, 38: 33-64

Kohl P L. 1981. The namazga civilization: An overview. Soviet Anthrop Archaeol, 19: vii-xxxviii

Kuijt I, Mahasneh H. 1998. Dhra': An early Neolithic village in the southern Jordan Valley. J Field Archaeol, 25: 153-161

Kuijt I, Goring-Morris N. 2002. Foraging, farming, and social complex- 
ity in the Pre-Pottery Neolithic of the southern Levant: A review and synthesis. J World Prehist, 16: 361-440

Kuz'mina E E. 2008. The Prehistory of the Silk Road. Philadelphia: University of Pennsylvania Press. 39-108

Lanehart R E, Tykot R H, Underhill A P, Luan F S, Yu H G, Fang H, Cai F S, Feinman G, Nicholas L. 2011. Dietary adaptation during the Longshan period in China: Stable isotope analyses at Liangchengzhen (southeastern Shandong). J Archaeol Sci, 38: 2171-2181

LeBlanc S, Watson P. 1973. A comparative statistical analysis of painted pottery from seven Halafian sites. Paléorient, 1: 117-133

Lee G A. 2011. The transition from foraging to farming in prehistoric Korea. Curr Anthropol, 52: S307-S329

Lee-Thorp J A. 2008. On isotopes and old bones. Archaeometry, 50: 925-950

Li C X, Li H J, Cui Y Q, Xie C Z, Cai D W, Li W Y, Victor M H, Xu Z, Zhang Q C, Abuduresule I, Jin L, Zhu H, Zhou H. 2010. Evidence that a West-East admixed population lived in the Tarim Basin as early as the early Bronze Age. BMC Biol, 8: 15

Lightfoot E, Matuzeviciute G M, O'Connell T C, Kukushkin I A, Loman V, Varfolomeev V, Liu X, Jones M K. 2015. How "pastoral" is pastoralism? dietary diversity in bronze age communities in the central Kazakhstan steppes. Archaeometry, 57: 232-249

Linduff K M, Mei J J. 2009. Metallurgy in ancient Eastern Asia: Retrospect and prospects. J World Prehist, 22: 265-281

Liu X Y, Lightfoot E, O'Connell T C, Wang H, Li S C, Zhou L P, Hu Y W, Matuzeviciute G M, Jones M K. 2014. From necessity to choice: Dietary revolutions in west China in the second millennium BC. World Archaeol, 46: 661-680

Liu X Y, Lister D L, Zhao Z J, Staff R A, Jones P J, Zhou L P, Pokharia A K, Petrie C A, Pathak A, Lu H L, Matuzeviciute G M, Bates J, Pilgram T K, Jones M K. 2016. The virtues of small grain size: Potential pathways to a distinguishing feature of Asian wheats. Quat Int, 426: 107-119

Lösch S, Grupe G, Peters J. 2006. Stable isotopes and dietary adaptations in humans and animals at pre-pottery Neolithic Nevallı Çori, southeast Anatolia. Am J Phys Anthropol, 131: 181-193

Lu H Y, Zhang J P, Liu K, Wu N Q, Li Y M, Zhou K S, Ye M L, Zhang T Y, Zhang H J, Yang X Y, Shen L C, Xu D K, Li Q. 2009. Earliest domestication of common millet (Panicum miliaceum) in East Asia extended to 10000 years ago. Proc Natl Acad Sci USA, 106: 7367-7372

Ma M M, Dong G H, Jia X, Wang H, Cui Y F, Chen F H. 2016. Dietary shift after $3600 \mathrm{cal}$ yr BP and its influencing factors in northwestern China: Evidence from stable isotopes. Quat Sci Rev, 145: 57-70

Ma Y, Fuller B T, Chen L, Zhao C, Hu Y, Richards M P. 2016. Reconstructing diet of the Early Qin (ca. 700-400BC) at Xishan, Gansu
Province, China. Int J Osteoarchaeol, 26: 959-973

Matuzeviciute G M, Lightfoot E, O'Connell T C, Voyakin D, Liu X, Loman V, Svyatko S, Usmanova E, Jones M K. 2015. The extent of cereal cultivation among the Bronze Age to Turkic period societies of Kazakhstan determined using stable isotope analysis of bone collagen. J Archaeol Sci, 59: 23-34

Matuzeviciute G M, Staff R A, Hunt H V, Liu X Y, Jones M K. 2013. The early chronology of broomcorn millet (Panicum miliaceum) in Europe. Antiquity, 87: 1073-1085

Matuzeviciute G M, Telizhenko S, Jones M K. 2012. Archaeobotanical investigation of two Scythian-Sarmatian period pits in eastern Ukraine: Implications for floodplain cereal cultivation. J Field Archaeol, 37: 51-60

Mei J J, Shell C. 1999. The existence of Andronovo cultural influence in Xinjiang during the 2nd millennium BC. Antiquity, 73: 570-578

Miller A V, Usmanova E, Logvin V, Kalieva S, Shevnina I, Logvin A, Kolbina A, Suslov A, Privat K, Haas K, Rosenmeier M. 2014. Subsistence and social change in central Eurasia: Stable isotope analysis of populations spanning the Bronze Age transition. J Archaeol Sci, 42: $525-538$

Moore A M T. 1992. The impact of accelerator dating at the early village of Abu Hureyra on the Euphrates. Radiocarbon, 34: 850-858

Moorey P R S. 1988. The Chalcolithic hoard from Nahal Mishmar, Israel, in context. World Archaeol, 20: 171-189

Nasu H, Momohara A, Yasuda Y, He J. 2007. The occurrence and identification of Setaria italica (L.) P. Beauv. (foxtail millet) grains from the Chengtoushan site (ca. 5800 cal B.P.) in central China, with reference to the domestication centre in Asia. Veget Hist Archaeobot, 16: $481-494$

Oates D. 1990. Innovations in mud-brick: Decorative and structural techniques in ancient Mesopotamia. World Archaeol, 21: 388-406

Perlès C. 2001. The Early Neolithic in Greece: The First Farming Communities in Europe. Cambridge: Cambridge University Press. $152-200$

Perlès C, Quiles A, Valladas H. 2013. Early seventh-millennium AMS dates from domestic seeds in the Initial Neolithic at Franchthi Cave (Argolid, Greece). Antiquity, 87: 1001-1015

Petroutsa E I, Manolis S K. 2010. Reconstructing Late Bronze Age diet in mainland Greece using stable isotope analysis. J Archaeol Sci, 37: 614-620

Pinhasi R, Pluciennik M. 2004. A regional biological approach to the spread of farming in Europe: Anatolia, the Levant, South-Eastern Europe, and the Mediterranean. Curr Anthropol, 45: S59-S82

Price T D, Bentley R A, Lüning J, Gronenborn D, Wahl J. 2001. Prehistoric human migration in the Linearbandkeramik of Central Europe. Antiquity, 75: 593-603 
Richards M P, Pearson J A, Molleson T I, Russell N, Martin L. 2003. Stable isotope evidence of diet at Neolithic Çatalhöyük, Turkey. J Archaeol Sci, 30: 67-76

Riehl S, Zeidi M, Conard N J. 2013. Emergence of agriculture in the foothills of the Zagros Mountains of Iran. Science, 341: 65-67

Roberts B W, Thornton C P, Pigott V C. 2009. Development of metallurgy in Eurasia. Antiquity, 83: 1012-1022

Robinson D E. 2003. Neolithic and Bronze Age agriculture in Southern Scandinavia-Recent archaeobotanical evidence from Denmark. Environ Archaeol, 8: 145-165

Rosenberg D. 2010. Early maceheads in the southern Levant: A "chalcolithic" hallmark in neolithic context. J Field Archaeol, 35: 204-216

Sergusheva E A, Vostretsov Y E. 2009. The advance of agriculture in the coastal zone of East Asia. In: Fairbairn A, Weiss E, eds. From Foragers to Farmers: Papers in Honor of Gordon C. Hillman. Oxford: Oxbow Books. 205-219

Sherratt A. 2006. The trans-Eurasian exchange: The prehistory of Chinese relations with the West. In: Mair V H, ed. Contact and Exchange in the Ancient World. Honolulu: Hawaii University Press. 32-53

Spengler R, Frachetti M, Doumani P, Rouse L, Cerasetti B, Bullion E, Mar'yashev A. 2014. Early agriculture and crop transmission among Bronze Age mobile pastoralists of Central Eurasia. Proc R Soc B-Biol Sci, 281: 20133382

Spengler R N, Willcox G. 2013. Archaeobotanical results from Sarazm, Tajikistan, an Early Bronze Age Settlement on the edge: Agriculture and exchange. Environ Archaeol, 18: 211-221

Spengler R N. 2015. Agriculture in the central Asian Bronze Age. J World Prehist, 28: 215-253

Tafuri M A, Craig O E, Canci A. 2009. Stable isotope evidence for the consumption of millet and other plants in Bronze Age Italy. Am J Phys Anthropol, 139: 146-153

Tengberg M. 1999. Crop husbandry at Miri Qalat Makran, SW Pakistan (4000-2000 B.C.). Veg Hist Archaebot, 8: 3-12

Vigne J D. 2011. The origins of animal domestication and husbandry: A major change in the history of humanity and the biosphere. Comptes Rendus Biologies, 334: 171-181
Wertime T A. 1973. The beginnings of metallurgy: A new look: Arguments over diffusion and independent invention ignore the complex metallurgic crafts leading to iron. Science, 182: 875-887

Willcox G. 1991. Carbonized plant remains from Shortughai, Afghanistan. In: Renfrew J M, ed. New Light on Early Farming: Recent Developments in Palaeoethnobotany. Edinburgh: Edinburgh University Press. 139-153

Yang Y S, Dong G H, Zhang S J, Cui Y F, Li H M, Chen G K, Dodson J, Chen F H. 2016. Copper content in anthropogenic sediments as a tracer for detecting smelting activities and its impact on environment during prehistoric period in Hexi Corridor, Northwest China. Holocene, 27: 282-291

Zeder M A. 2008. Domestication and early agriculture in the Mediterranean Basin: Origins, diffusion, and impact. Proc Natl Acad Sci USA, 105: 11597-11604

Zeder M A, Hesse B. 2000. The InitialInitial domestication of goats (Capra hircus) in the Zagros Mountains 10000 years ago. Science, 287: 2254-2257

Zhang G L, Wang S Z, Ferguson D K, Yang Y M, Liu X Y, Jiang H E. 2015. Ancient plant use and palaeoenvironmental analysis at the $\mathrm{Gu}-$ mugou Cemetery, Xinjiang, China: Implication from desiccated plant remains. Archaeol Anthropol Sci, 9: 145-152

Zhao Z J. 2009. Eastward spread of wheat into China-New data and new issues. Chin Archaeol, 1: 1-9

Zhao Z J. 2011. New archaeobotanic data for the study of the origins of agriculture in China. Curr Anthropol, 52: S295-S306

Zhao K L, Li X Q, Zhou X Y, Dodson J, Ji M. 2013. Impact of agriculture on an oasis landscape during the late Holocene: Palynological evidence from the Xintala site in Xinjiang, NW China. Quat Int, 311: 81-86

Zohary D, Hopf M, Weiss E. 2012. Domestication of Plants in The Old World: The Origin and Spread of Domesticated Plants in Southwest Asia, Europe, and the Mediterranean Basin. 4th ed. Oxford: Oxford University Press. 9-17

Zvelebil M, Dolukhanov P. 1991. The transition to farming in Eastern and Northern Europe. J World Prehist, 5: 233-278 